\title{
LABOR RELATIONS UNDER THE CONTEMPORARY HUMAN DEVELOPMENT: COMPARATIVE ASPECT
}

\author{
Zapara S. I., Kravchenko I. O.
}

\section{INTRODUCTION}

A famous Israel historian Juval Noah Harari in the World Economic Forum in Davos noted that in the third millennium of the $21^{\text {st }}$ century, humanity faced many problems and issues threatening the survival of human species. This is a nuclear war, environmental collapse and technological breakthrough. According to Juval Noah Harari, a nuclear war and environmental collapse are the threats we have already been informed of, but the technological breakthrough needs to be explained, as it is also capable of imbalancing human society and changing the meaning of human life in various ways - from the creation of world-class consumption to the emergence of colonialism and the emergence of data colonialism and digital dictatorship. In any case, technological change has a direct impact on human values, habitual lifestyle, communication, education, new digital competencies, economic productivity, digital capitalism, social rights, privacy issues and access to information, etc. Understanding and characterizing these issues is a key to understanding new digital social reality and identifying the opportunities, challenges and threats of the $4^{\text {th }}$ industrial revolution.

Let us note that the term "The Fourth Industrial Revolution" ("The Fourth Industrial Revolution") is a concept that means the development and merger of automated production, data sharing and production technology into a single selfregulating system, with little or no human intervention in the production process. The term has been defined as a "collective concept for value chain technology and concepts" using cyber-physical systems, the Internet of things, the Internet of services, and smart factories. The phase of the industrial revolution is characterized by the fusion of technologies that blur the boundaries between the physical, digital and biological spheres. Industry 4.0 will enable to collect and analyse data from different machines, providing faster, more efficient and flexible processes for producing higher quality goods at reduced prices. It has also led to the emergence of brand new business models that will promote radically new ways of interacting in the value chain ${ }^{1}$.

\footnotetext{
1 Schwab Klaus. The Fourth Industrial Revolution: what it means, how to respond. URL: https://www.weforum.org/agenda/2016/01/the-fourth-industrial-revolution-what-it-means-and-how-to-respond (дата звернення: 03.24.2020).
} 
The first industrial revolution has led to the transition from manual to mechanized production through the use of a steam engine, the second industrial revolution has led to the transition to mass production, through the use of electric motor and conveyor, the third industrial revolution has resulted in the transition to automated production through the use of computers and information technology. The term "Industrie 4.0" first became known in April 2011, when the "Industrie 4.0" group at the Hanover Fair launched an initiative to improve the competitiveness of the German economy ${ }^{2}$. The Fourth Industrial Revolution involves the transformation of labor and social relations changes connected with the use of new technologies.

The consequences of the pandemic on the Covid-19 are no less of a challenge for the future social and labor relations in Ukraine and in the world. Discussion is now underway as to the possible effective overcoming of the effects of coronavirus in the field of social and labor relations.

New predictions and expectations are emerging, which in most cases signal to society that irreversible changes are first and foremost, from extremely restrictive to optimistic and humanistic. According to a trend expert Lee Edelcourt, "Breaking is inevitable $\langle\ldots\rangle$, a global-scale coronavirus pandemic will force people to restore humanist values"3. A positive consequence of the catastrophe of a planetary scale (coronavirus), according to L. Edelcourt, will be the creation of a new system of labor relations and greater respect for everyone's work, the emergence of more comfortable conditions of production. The introduction of quarantine will encourage employers to find new formats of events, as well as innovative ways of transmitting information ${ }^{4}$.

In any case, altered social reality already includes a number of factors and circumstances that affect social equilibrium and stability. The prerequisites of this study are the objective monitoring of the state of social and labor relations in Ukraine and other countries of the world, the analysis of urgent issues of alternative employment, the global crisis and crisis of the human rights mechanism of social and labor relations, changes in the legal status and powers of trade union organizations. These institutions are intended to protect the interests of employees, development of "individualization" of labor relations and new forms of protecting employees' rights and interests.

\footnotetext{
${ }^{2}$ Hermann Mario, Pentek Tobias. Design Principles for Industriea Literature Review. Technische Universit at Dortmund. URL: http://www.iim.mb.tu-dortmund.de/cms/de/forschung/Arbeitsberichte/Design-Principles-forIndustrie-4_0-Scenarios.pdf (дата звернення: 24.03.2020).

3 Edelcourt Lee. How entertainment, work and shopping will change. The trendsetter told about the effects of coronavirus on the world. URL: https://tsn.ua/svit/yak-zminyatsya-rozvagi-robota-ta-pokupki-ekspertka-ztrendiv-rozpovila-pro-naslidki-koronavirus-dlya-svitu-1510821.html (дата звернення: 24.03.2020).

${ }^{4}$ Edelcourt Lee. How entertainment, work and shopping will change. The trendsetter told about the effects of coronavirus on the world. URL: https://tsn.ua/svit/yak-zminyatsya-rozvagi-robota-ta-pokupki-ekspertka-ztrendiv-rozpovila-pro-naslidki-koronavirus-dlya-svitu-1510821.html (дата звернення: 24.03.2020).
} 
Ukraine, like most countries in the world, has faced the problem of "resetting" social and labor relations. Transformations concern a number of issues: the emergence of new professions against the backdrop of the disappearance of others, the development of "atypical employment", the total need for "work at home", "additional" control while performing work functions, the formation of new boundaries of personal privacy, part-time work, increasing retirement age, the constant need for retraining. And it is not the whole list of new challenges that arise in the field of social and labor relations.

Conditionally, in our opinion, existing challenges can be divided into several groups, each of which needs attention and scientific analysis.

The first group of problems, protection of labor rights in modern relations has a global character and includes features of the development of technological progress, digitalization of society. It is believed that technological progress brings prosperity, freedom and even immortality to humanity. But with the new world order, there are new challenges and threats. One should not forget the lessons of history, when in 1928 the Weimar government used the phrase "Arbeit macht frei" as a slogan for a major community service program aimed at overcoming unemployment, and was later placed at the entrance of many Nazi concentration camps. Without exaggeration, the development of social-labor relations, as well as many other spheres of human life, requires, above all, a valuable understanding of the prospects and possibilities of the consequences of the technological revolution.

According to many experts, in the next ten - twenty years, about 60 professions will disappear from the list of topical professions, including accountant, legal advisor, notary, journalist, librarian, pharmacist, translator, lending manager, waiter, trainer, courier and more. Along with this, as a result of the technological revolution, about 170 new professions will emerge in the atlas of new professions ${ }^{5}$, such as virtual lawyer, IT physician, medical equipment architect, bioethicist, genetic consultant, smart home infrastructure designer, personal security designer, unmanned aviation interface designer, creative state trainer, game master, media police, and more.

A great deal of prerequisites, from individual inventions (invented by waiters, automatic translation programs, etc.) to the "digitization" of society (from virtual money to entire systems of "digitization" of data, real estate, etc.), have already been created for these changes. For example, Alexander Kud notes that "blockchain" is a multifunctional and multilevel information technology designed to securely store, record and transmit various information. The potential of using this technology covers all spheres of society and has many

\footnotetext{
${ }^{5}$ Atlas of new professions. URL: http://atlas100.ru/catalog/ (дата звернення: 03.24.2020).
} 
applications. Blockchain creates new opportunities for finding, evaluating, and transmitting any discrete units. In essence, it is a new organizational paradigm for coordinating any kind of activity ${ }^{6}$.

There is no doubt that in the event of full implementation of technological changes, the organization of labor also undergoes significant changes. For example, job vacancies can become widespread resulting in labor collapse and unsupervised social protests. Challenge forecasting may be aimed at mitigating negative effects, creating lifelong learning institutions, retraining, psychological and social-labor adaptation to changing labor markets.

The implementation of labor in many cases is associated with the need to use technology in production, high labor intensification, excessive demand for workers. The issue of privacy is often raised as a result of video surveillance. The impact and effects of this process on the human condition have not been fully explored. Modern science is not often limited to general conclusions, studies only some cases of the impact of technological progress on humans. In our opinion, not only the issue of the impact of technological change on the method and content of legal regulation of labor relations, but also question of the sufficiency of the mechanisms of protection of labor rights in the conditions of technological change, is important.

Environmental disasters of man-made phenomena, pandemics, etc. are also a global challenge. The latest example that has shaken the world is the Covid-19 epidemic.

A letter ${ }^{7}$ has been recently published on behalf of the International Chamber of Commerce (ICC) representing more than 445 million companies, enterprises and International Trade Union Confederation (UPC), representing workers from around the world to Heads of State and Government of the Group of 20.The appeal to world leaders emphasizes fight against the Covid-19 pandemic and the halt in the growing humanitarian and economic impact of the coming crisis, which by its very nature has no borders. The appeal emphasizes not only the need for integration and solidarity in terms of providing the goods of the required group (medicines, food and other vital goods), but also the intensification of support for small and medium-sized businesses and employees. It is noted that the impact of Covid-19 will be grave on the micro, small and medium-sized enterprises that are the backbone of the global economy. In many countries, this is more than $80 \%$ of employed. There is a

\footnotetext{
${ }^{6}$ Digital assets and their economic and legal regulation in the light of the development of blockchain technology : monograph / Alexander Kud, Mykola Kucheryavenko, Evgeny Smychok. Kharkiv : Law, 2019. 384 p. P. 12.

${ }^{7}$ ITUC-ICC. Open letter to the G20 Heads of State and Government_Ru. March 23, 2020. ITUC : Website. URL: https://www.facebook.com/permalink.php?story_fbid=1400220720149864\&id=100004858480395 (дата звернення: 03.24.2020).
} 
need to take urgent measures to protect and encourage micro, small and medium-sized enterprises, to support the income of injured workers, including in the informal sector, and to prevent the sharp rise of unemployment. There is a need to expand the social protection program for workers who have lost their jobs as a result of quarantine.

It becomes obvious that mankind has met one of the obstacles that may be repeated. This forces authorities to focus on preventative measures and / or respond promptly to the negative consequences of a particular problem. In the end, the positive effect depends on the coherence of the actions of public services and the public perception of necessary rules.

One of the successful examples of the fight against this pandemic is Singapore. This has become possible because of careful and prompt actions of the authorities, through which it has been possible to form a system of detection of infection chain. It is about prompt tracking of cases of infection and rapid deployment of diagnostic systems. In particular, in February a decision was made to oblige anyone who entered government or corporate premises to leave their contact information. This greatly accelerated the work of medical "detectives"

The second component of Singapore's success is the rapid development and deployment of diagnostic tests. This has enabled to check every person arriving in the country and identify the patients in a timely manner for three-hour quarantine. The above examples demonstrate not only the quality of medicine, but these issues are directly linked to three pressing issues: 1) institutional capacity, such as the quality of crisis management, government action, the ability to mobilize the necessary material and human resources promptly to solve pressing problems; 2) economic capacity. Turning to the problem of the economic impact of a pandemic, it is important to provide necessary minimum for a certain period of time, that is enough for self-recovery for workers, their families, support for small and medium-sized businesses. The state should focus on helping workers get paid sick leave and keep jobs. In this context, social dialogue plays an important role without exaggeration, as a result of which a reasonable proportion of general and personal interest is formed; 3) willingness to apply a system of restrictive measures. The result of the fight against the Covid-19 coronavirus has shown a greater ability of the People's Republic of China to deal with a pandemic. However, the effectiveness of the authorities' prompt actions is not infrequently linked to the imposition of additional restrictions on social rights and freedoms, which, in the face of danger, seem justified. But could restrictive actions be effective in short term?

\footnotetext{
8 Kolenov Sergey. As Singapore became a model example of the fight against coronavirus URL: https://hightech.plus/2020/03/13/akak-singapur-stal-obrazcov-primer-borbi-s-koronavirus (дата звернення: 03.24.2020).
} 
In order to stop the pandemic, the authorities use modern technologies that limit personal freedoms. "Today, for the first time in history, technology allows it, and some governments (the most notable example is China) have already taken the following measures: using ubiquitous sensors and powerful algorithms, they monitor the temperature and condition of potentially infected people, their moving and contacts. Mobile apps alert healthy people to the virus carrier approaching them. And this is not only the case in East Asian countries. Israel Prime Minister Benjamin Netaniahu has recently allowed Israel intelligence to track patients with coronavirus using surveillance technology commonly used in the fight against terrorism",

Obviously, it is too early to conclude and summarize the effects of global crisis and how individual countries respond to it. But today, new restrictions on the rights and freedoms of citizens are becoming apparent and real. Imagine that the case of a pandemic outbreak, self-isolation, border closure, restriction of liberties is not alone and threatens humanity with recurrence. Does this mean that the ratio of major liberal values is changing?

The second group of problems is related to the institutional crisis of labor rights protection. In view of the above, we need to talk about the general crisis of the development of social-labor relations, to look for new ideas of legal regulation of social-labor relations, among which the topic of protection of the latter occupies one of key positions. Obviously, if the situation does not change in the near future, human rights mechanism will not be able to rely, as before, on the assumption that the trade union is main (or only) body of workers who protects the social sphere and labor relations professionally. The relevance of the research topic was confirmed by the discussion platform of the Association of Labor and Employment Association (LERA) conference, held in June 2019 ${ }^{10}$, and focused on issues of trust in trade union organizations, reducing the number of trade union members, developing forms of legal protection for social and labor relations. Against this background, much attention is paid to widespread scholarly discussions of leading scholars of the world, as outlined in such publications as Comparative Labor Law, edited by Matthew W. Finkin (University of Illinois, USA) ${ }^{11}$.

\footnotetext{
${ }^{9}$ Yuval Noah Harari. How the coronovirus will change the world. URL: https://litgazeta.com/news/iuval-nojkharari-iak-koronavirus-

zminytsvit/?fbclid=IwAR2EkC51AAb7c7WUOuZI9uytij4t9xKhFj7TXRMPD1_00qQVt0.20xeq.20xe.20xeq.20x e.20xeRL.

10 Ahead of the Curve: Challenges Posed by Technology and the New Workforce LERA 71st Annual Meeting, June 13-16, 2019, Cleveland, Ohio Preconference Day. June 12, 2019. URL: https://www.leraweb.org/lera- 71st-annual-meeting-information (дата звернення: 03.24.2020).

${ }^{11}$ Metthew W. Finkin, Guy Mundlak Comparative Labor Law. Cheltenham, UK Northampton, MA, USA. 2015. $491 \mathrm{p}$.
} 
The natural question arises as to the effectiveness of existing and alternative mechanisms for the protection of workers' rights. The curve of the diminishing role of trade unions in the previous period of development of social and labor relations may have a different perspective on new societal challenges. Trade unions have needed social experience and potential to form and develop social dialogue, which is crucial in a crisis. After all, the balance of public interests is of particular importance during the global crisis.

The third group of problems related to national peculiarities of formation and development of social-labor relations. Of course, against the background of the lack of a uniform standard of employment for all countries, each country chooses its own path of evolution of labor relations. Guided only by a beacon of general rules - the European Social Charter (Updated), the Conventions, the ILO Recommendations, each country freely implements its own platform for the development of social and labor relations.

One example that deserves attention is proportionality of general and personal interest in regulating working time. The Sweden experience in reducing working hours to 6 hours a day, for the benefit of family interests, has found receptive audience. The following question arises: How can the issue of working time (the need for its flexibility) be compared to the needs of family life? The right is intended to regulate social relations, to respond adequately to human needs. The last example of forced self-isolation demonstrated the public's unwillingness to address the problems of family life and work. After switching quarantine to schools and kindergartens, workers who do not have the opportunity to work remotely are left alone with problems of family life, relationships with children and more. In the face of global challenges, society must demonstrate a readiness for social dialogue and consensus. Instead, opposite situations occur.

The Government of Ukraine has recently announced the reform of social and labor relations. The proposed changes have met strong public resistance, and for reason. For example, in order to reform social and labor relations, draft laws were drafted "On Labor", "On Amendments to Certain Legislative Acts of Ukraine (Concerning Some Issues of Activity of Trade Unions)", "On Amendments to the Labor Code of Ukraine on Additional grounds for dismissal", which, according to many experts, ${ }^{12}$ contradict the norms of the International Labor Organization, the Constitution of Ukraine, and the applicable legal acts.

\footnotetext{
12 Opinion of the Institute of State and Law. V.M. Koretsky on changes to the labor law. URL: http://www.fpsu.org.ua/259-slajder-izbrannykh-novostej/17351-visnovok-institutu-derzhavi-i-prava-im-vmkoretskogo-shchodo-zmin-do-trudovogo-zakonodavstva-2.html (дата звернення: 03.24.2020).
} 
We should add that repeated attempts in Ukraine to reform the legal regulation of labor relations have failed. In addition, there are new challenges related to the gradual dismantling of a system based on the obligation to conclude an employment contract. Atypical employment in Ukraine has already taken on a real shape, but has not been regulated legally and sufficiently yet. Therefore, one of the urgent problems is the recognition and legalization in Ukraine of "flexible" forms of employment. It should be noted that Ukrainian labor market, like the European labor markets, is primarily faced with the problem of combining greater flexibility with the need to maximize security for all. The desire for flexibility in labor market has led to an increase in the variety of contractual forms of employment that may differ significantly from the standard contractual model in terms of employment and income security and the relative stability of their associated working and living conditions.

Another attempt to reform social and labor relations in Ukraine has resulted in the government failure. In our opinion, the reform of social and labor relations should be preceded by a broad discussion of participants to these relations, followed by the adoption of the logic of proposed changes. Therefore, in reforming existing social relations, an important factor in stabilizing the latter is social dialogue between the authorities, representatives of employers, trade unions, and other participants in social relations.

Social dialogue helps identify problems of legal regulation in a timely manner and, subsequently, work out ways to solve them. A similar example of social dialogue in December 2019 in Kyiv is the discussion under the ILO Technical Cooperation Project "Inclusive Labor Market for Job Creation" held at the national round table "Towards Effective, Influential and Inclusive Social Dialogue in Ukraine", organized by the ILO in conjunction with the Verkhovna Rada of Ukraine Committee on Social Policy and Veterans' Rights. More than 70 people took part in this event: People's Deputies of Ukraine, representatives of the government, organizations of employers and trade unions, civil society, scientific institutions, independent consultants, experts. Thus, during the discussion the participants of the round table noted the reasons for the inefficiency of current national model of social dialogue:

- reduction in political support for functioning of social dialogue bodies and other mechanisms aimed at achieving coordination of ways of overcoming problems in the sphere of economy and social policy, as well as the passivity of social partners in the desire to achieve the effectiveness of social dialogue;

- unawareness of newly appointed heads of central and local executive bodies in matters of organization and conducting of social dialogue, place and role of authorities in interaction with social partners; 
- social partners unilaterally interact with the authorities to defend their interests, but do not seek to reach an agreement by modifying their own interests to identify and realize the common interests of the parties;

- inconsistency of structure of organizations of employees and employers with the structure of economy and territorial structure: a significant percentage of small and micro enterprises not covered by membership in these organizations; the lowest statutory status of organizations is local, which does not include membership in United Territorial Communities (ATGs). At the same time, $68 \%$ of the survey respondents believe that the lowest territorial level of social dialogue is the CAG;

- lack of responsiveness to the challenges of time, insignificant impact of decisions taken in the framework of social dialogue at national level on employment policy on social, economic and budgetary policies;

- ignoring the views of employees "and employers" representatives when making decisions on regulating social and labor relations (this was especially emphasized in the process of drafting a new labor code);

- limited access of "non-representative" trade unions and employers" organizations to participate in the formation and adoption of agreed decisions on issues that are the subject of social dialogue;

- inconsistency of coverage of enterprises of certain types of economic activity by sectoral organizations of social partners, which greatly limits the scope of sectoral agreements after their conclusion.

\section{CONCLUSIONS}

The identification and analysis of acute problems of social and labor relations create preconditions for their development and positive dynamics. Instead, avoiding dialogue produces social conflict, exacerbates social confrontation, and threatens social stability.

Summarizing the above, it should be noted that the global economic crisis is bringing humanity both obstacles and opportunities. The effect of the global crisis is exacerbated by the peculiarities, weaknesses of national economies, combined by unfavorable conditions for the development of social and labor relations. The above is compounded by institutional crisis of protecting the interests of employees. According to many experts, the union protection institute associated with other institutions protecting the rights of participants in social and labor relations is also in crisis.

In any case, anthropological changes of a revolutionary nature, new possibilities of regulation of labor relations, expansion of remote possibilities of performance of work, formation of new social bonds with the help of modern technologies await us. 
Along with new opportunities, there are also risks of forming and developing a scenario of total control. After all, the use of modern technologies, from the possibilities of using quantum computers to exercising control over human emotions, the need to overcome the effects of global crisis, new forms of management of labor processes can create the preconditions for the formation of a personless, digitized blurred collective human mind. And this is one of the significant challenges of today. Only a responsible citizen, who understands the value of challenges and is able to adequately respond to modern problems, can give a proper assessment to the public relations and actions of authorities, solve complex social problems due to social dialogue.

\section{SUMMARY}

Technological changes directly influence human values, way of life, communication, education, new digital competencies, economic productivity, digital capitalism, social rights, social rights, privacy issues and access to information, etc. The understanding and description of these issues is a key to understanding new digital social reality and identifying the opportunities, challenges, and threats of $4^{\text {th }}$ industrial revolution.

The prerequisites of this study are the objective monitoring of the state of social and labor relations in Ukraine and other countries of the world, the analysis of urgent issues of alternative employment, the global crisis and crisis of the human rights mechanism of social and labor relations, changes in the legal status and powers of trade union organizations. These institutions are intended to protect the interests of employees, development of "individualization" of labor relations and new forms to protect employees' rights and interests.

Ukraine, like most countries in the world, has faced the problem of "resetting" social and labor relations. Transformations concern a number of questions: the emergence of new professions against the backdrop of the disappearance of others, the development of "atypical employment", the total need for "work at home", "additional" control while performing work functions, the formation of new boundaries of personal privacy, part-time work, increasing retirement age, the constant need for retraining. And it is not the whole list of new challenges that arise in the field of social and labor relations.

According to the authors of this article, along with the window of new opportunities, there are also risks of forming and developing a scenario of total control. The use of modern technologies, from the power of quantum computers to the control of human emotions, the need to overcome the consequences of the global crisis, new forms of labor processes management may create the prerequisites for the formation of "impersonal", "digitized", "blurred" collective human mind. And this is one of significant challenges nowadays. Only a 
responsible citizen, who understands the value of these challenges, can give a proper assessment to the public relations and actions of authorities, and solve complex social problems with the help of social dialogue.

\section{REFERENCES}

1. Schwab Klaus. The Fourth Industrial Revolution: what it means, how to respond. URL: https://www.weforum.org/agenda/2016/01/the-fourth-industrialrevolution-what-it-means-and-how-to-respond (дата звернення: 24.03.2020).

2. Hermann Mario, Pentek Tobias. Design Principles for Industrie a Literature Review. Technische Universitat Dortmund. URL: http://www.iim.mb.tudortmund.de/cms/de/forschung/Arbeitsberichte/Design-Principles-for-Industrie4_0-Scenarios.pdf (дата звернення: 24.03.2020).

3. Еделькорт Лі. Як зміняться розваги, робота та покупки. Експертка із трендів розповіла про наслідки короновірусу для світу. URL: https://tsn.ua/svit/yak-zminyatsya-rozvagi-robota-ta-pokupki-ekspertka-z-trendivrozpovila-pro-naslidki-koronavirusu-dlya-svitu-1510821.html (дата звернення: 24.03.2020).

4. Атлас нових професій. URL: http://atlas100.ru/catalog/ (дата звернення: 24.03.2020).

5. Цифрові активи та їх економіко-правове регулювання у світлі розвитку технології блокчейн : монографія / Александр Кудь, Микола Кучерявенко, Євген Смичок. Харків : Право, 2019. 384 с.

6. ITUC-ICC. Open letter to G20 Heads of State and Government_Ru. Открытое письмо к главам государств и правительств стран Группы 20. 23 марта 2020 г. ITUC : сайт. URL: https://www.facebook.com/permalink.php? story_fbid=1400220720149864\&id=100004858480395 (дата звернення: 24.03.2020).

7. Коленов Сергей. Как Сингапур стал образцовым примером борьбы с короновирусом. URL: https://hightech.plus/2020/03/13/kak-singapur-stalobrazcovim-primerom-borbi-s-koronavirusom (дата звернення: 24.03.2020).

8. Юваль Ной Харарі. Як короновірус змінить світ. URL: https://litgazeta.com.ua/news/iuval-noj-kharari-iak-koronavirus-zminytsvit/?fbclid=IwAR2EkC51AAb7c7WUOuZI9uytij4t9xKhFj7TXRMPDI_00qQV t0xeRLq-h14 (дата звернення: 24.03.2020).

9. Ahead of the Curve: Challenges Posed by Technology and the New Workforce LERA $71^{\text {st }}$ Annual Meeting, June 13-16, 2019, Cleveland, Ohio Preconference Day. June 12, 2019. URL: https://www.leraweb.org/lera-71stannual-meeting-information (дата звернення: 24.03.2020).

10. Metthew W. Finkin, Guy Mundlak Comparative Labor Law. Cheltenham, UK Northampton, MA, USA. 2015. 491 p. 
11. Висновок Інституту держави і права ім. В.М. Корецького щодо змін до трудового законодавства. URL: http://www.fpsu.org.ua/259-slajder-izbrannykhnovostej/17351-visnovok-institutu-derzhavi-i-prava-im-v-m-koretskogo-shchodozmin-do-trudovogo-zakonodavstva-2.html (дата звернення: 24.03.2020).

Information about authors: Zapara S. I., Doctor of the Sciences, Professor, Dean of Law Department Sumy National Agrarian University 160, Gerasima Kondratieva str., 40000, Sumy

Kravchenko I. O.,

Doctor of the Sciences, Advocate, Senior Assistant at the Chair of Administrative and Informational Law Sumy National Agrarian University 160, Gerasima Kondratieva str., 40000, Sumy 